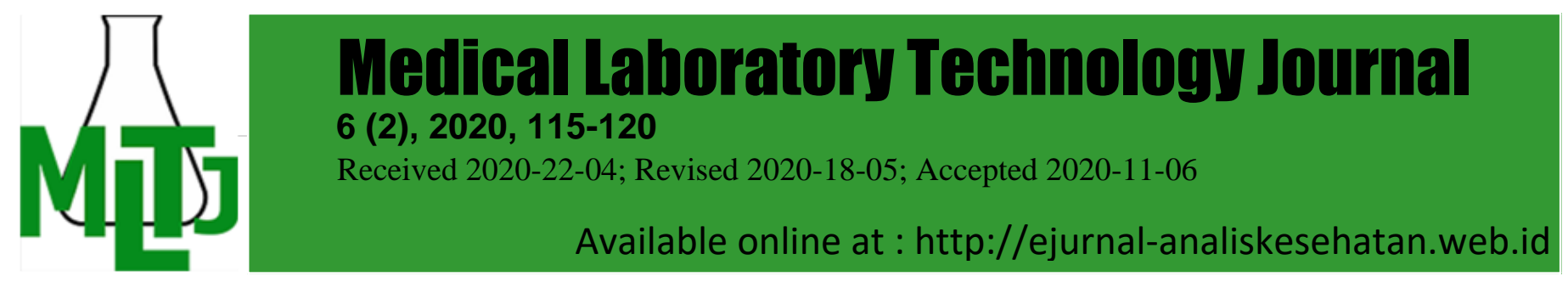

\title{
The Effects of Hyperbaric Oxygen Therapy on Blood Glucose Levels and Lipid Profile in Diabetes Mellitus Patients
}

\author{
${ }^{*}$ Andika Aliviameita1 ${ }^{1}$ Nevy Elensya1 ${ }^{1}$ Puspitasari', Sri Mukhodim \\ Faridah Hanum ${ }^{2}$
}

${ }^{1}$ Department of Medical Laboratory Technology, Faculty of Health Science Universitas Muhammadiyah Sidoarjo, Indonesia. ${ }^{2}$ Department of Midwifery, Faculty of Health Science Universitas Muhammadiyah Sidoarjo, Indonesia.

*Email: aliviameita@umsida.ac.id

DOI: 10.31964/mltj.v0i0.307

\begin{abstract}
Diabetes mellitus and its complications are still a major health problem in the world. Diabetes mellitus is closely related to the lipid profile, especially concerning the cardiovascular disease. A method that can be used to treat diabetes mellitus is hyperbaric oxygen therapy (HBOT). This study aims to observe changes in blood glucose levels and lipid profiles in patients with diabetes mellitus with hyperbaric oxygen therapy. The determination of blood glucose levels and lipid profiles is done by photometry. A total of 30 patients with diabetes mellitus examined for their blood glucose level and lipid profile before and after hyperbaric oxygen therapy. In the Paired T-test, there were significant decrease in blood glucose levels $(p=0,000)$, total cholesterol $(p=0,000)$, and triglycerides $(p=0,000)$ after hyperbaric oxygen therapy. The conclusion of this study shows there is a significant decrease in blood glucose level and lipid profile (total cholesterol, and triglycerides) after hyperbaric oxygen therapy.
\end{abstract}

Keyword: hyperbaric oxygen therapy; glucose; lipid profile; diabetes mellitus

\section{INTRODUCTION}

Diabetes mellitus and its complications are still a significant public health problem, as well as a cause of increased morbidity, mortality, and disability. In patients with diabetes mellitus, chronic metabolic disorders occur with a variety of causes. Increased blood glucose levels characterize these, accompanied by impaired carbohydrate, lipid, and protein metabolism as a result of insulin function insufficiency (Poretsky, 2010; Ndisanget al., 2017). The number of people with diabetes mellitus in East Java in 2018 ranks $5^{\text {th }}$ in Indonesia. The prevalence of people with diabetes mellitus aged $\geq 15$ years has increased from $6.9 \%$ in 2013 to 8.5\% in 2018 (Kemenkes RI, 2018). Research shows that being overweight results in abdominal obesity, which causes cardiovascular disease and increases the risk of type 2 diabetes mellitus. Patients with obesity are at risk of developing hypertension, dyslipidemia, and hyperglycemia (Tangvarasittichai, 2017).

Along with technological advances in the health sector, some methods can be used in efforts to treat diabetes mellitus, namely hyperbaric oxygen therapy. Hyperbaric oxygen therapy is the use of $100 \%$ oxygen at pressures higher than atmospheric pressure. The patient will gradually inhale $100 \%$ oxygen, along with an increase in therapeutic chamber pressure to more than one absolute atmosphere (ATA). This therapy initially used to relieve the symptoms of decompression after diving, which occurs due to changes in pressure, such as when diving or boarding an airplane, which is the release and expansion of gas bubbles in the organs. If we 
return to the initial pressure, there will be changes in pressure that can interfere withthe function of several organs/ decompression sickness. Hyperbaric oxygen therapy also developed to complement the effects of radiation on cancer care, supporting care during cardiac surgery, and carbon monoxide poisoning (Sourabh\&Guruswamy, 2012; Shahriariet al., 2014).

Hyperbaric oxygen therapy can improve and increase the amount of oxygen in the body, and have a significant impact on various clinical diseases, burns, poststroke, fractures, and acute and chronic ischemia (Lakesla, 2009). Hyperbaric oxygen therapy can also increase tissue sensitivity to insulin so that it can reduce high blood glucose levels in people with diabetes mellitus (Zaetunet al., 2015). Zakiyah\&Anggraini's research (2019) shows a significant difference in blood glucose levels after HBOT. Putri\&Setianingsih's research (2019) obtained significant differences in lipid profile levels in white rats (Rattusnorvegicus) induced by high-fat diets and given hyperbaric oxygen therapy. Research results in Turkey have a significant effect on blood glucose levels and lipid profiles after HBOT (Karadurmuset al., 2010). However, it is different from Semadi\&Irawan's (2017) study, which obtained an insignificant decrease in blood glucose levels after hyperbaric oxygen therapy and a significant increase in lipid profile levels. The study was conducted generally in diabetes mellitus patients with foot ulcers, which obtained a difference results were significant and not significant. From this background, it is necessary to observe the effect of HBOT on diabetes mellitus patients in general, to observe the effect of HBOT on blood glucose levels and their lipid profile.

\section{MATERIALS AND METHOD}

This research is experimental laboratories using blood samples of patients with diabetes mellitus before and after hyperbaric oxygen therapy. The certificate of ethics obtained from the Ethics Commission of the Faculty of Dentistry, Airlangga University, Surabaya, Indonesia, with a number of ethical clearance certificate: 070/ HRECC.FODM/II/2020. Hyperbaric oxygen therapy (HBOT) using 2.4 ATA highpressure oxygen in a special room with hyperbaric chamber oxygen for ten patients per session for 2 hours. The study conducted at the TiandteGedanganSidoarjo clinic in March 2020. This study used 30 blood samples of diabetes mellitus patients in the Tiandte Gedangan Sidoarjo clinic, with glucose levels $>200 \mathrm{mg} / \mathrm{dl}$. Determination of glucose, total cholesterol, and triglyceride levels in the blood using a photometer Wap Lab WP-9200 at a wavelength of $546 \mathrm{~nm}$. Blood glucose levels using the GODPAP method, total cholesterol by the CHOD-PAP method, and triglycerides by the GPO-PAP method. Data were analyzed statistically by Paired T-Test using SPSS 22.

\section{RESULTS AND DISCUSSION}

The characteristics of the research subjects according to gender and age are shown in Table 1. 30 research subjects were consisting of $30 \%$ men and $70 \%$ women. Based on age, there were $33.3 \%$ of patients with diabetes mellitus aged $40-$ 49 years, $30 \%$ of patients aged $50-59$ years, $20 \%$ aged $60-69$ years, and $16.7 \%$ aged $70-79$ years. There are $33.3 \%$ of patients with diabetes mellitus range in age from 40-49 years. Women of reproductive age (over 40 years) have a higher risk of developing diabetes mellitus than men. This is because physically, women have a higher chance of experiencing an increase in body mass index. Monthly and postmenopausal cycle syndromes result in the distribution of body fat that quickly 
accumulated due to hormonal processes that are at risk of suffering from type 2 diabetes (Wahyuni\&Alkaff, 2013).

The results of the average glucose, total cholesterol, and triglyceride levels before and after the patient's hyperbaric oxygen therapy decreased (Table 2). The average blood glucose level before and after HBOT has decreased from $307 \mathrm{mg} / \mathrm{dl}$ to $269 \mathrm{mg} / \mathrm{dl}$. The mean total cholesterol level also decreased from $270 \mathrm{mg} / \mathrm{dl}$ before HBOT to $241 \mathrm{mg} / \mathrm{dl}$ after HBOT. Similarly, the average triglyceride levels before and after HBOT decreased from $286 \mathrm{mg} / \mathrm{dl}$ to $258 \mathrm{mg} / \mathrm{dl}$. The diagram of the data can be seen in Figure 1.

Table 1. Characteristics of Research Subjects

\begin{tabular}{cllccc}
\hline No. & Variable & Category & Frequency & Percentage (\%) & Total (\%) \\
\hline 1. & Gender & Man & 9 & 30 & 100 \\
& & Woman & 21 & 70 & \\
2. Age & $40-49$ years & 10 & 33,3 & \\
& & $50-59$ years & 9 & 30 & 100 \\
& & $60-69$ years & 6 & 20 & \\
& & $70-$ years & 5 & 16,7 & \\
\hline
\end{tabular}

Table 2. Average \pm SD Glucose, Total Cholesterol, and Blood Triglyceride Levels

\begin{tabular}{cccccc}
\hline \multicolumn{3}{c}{ Before HBOT } & \multicolumn{3}{c}{ After HBOT } \\
\hline $\begin{array}{c}\text { Glucose } \\
(\mathrm{mg} / \mathrm{dl})\end{array}$ & $\begin{array}{c}\text { Total } \\
\text { Cholesterol } \\
(\mathrm{mg} / \mathrm{dl})\end{array}$ & $\begin{array}{c}\text { Triglycerides } \\
(\mathrm{mg} / \mathrm{dl})\end{array}$ & $\begin{array}{c}\text { Glucose } \\
(\mathrm{mg} / \mathrm{dl})\end{array}$ & $\begin{array}{c}\text { Total } \\
\text { Cholesterol } \\
(\mathrm{mg} / \mathrm{dl})\end{array}$ & $\begin{array}{c}\text { Triglycerides } \\
(\mathrm{mg} / \mathrm{dl})\end{array}$ \\
$307 \pm 73.122$ & $270 \pm 49.040$ & $286 \pm 75.663$ & $269 \pm 68.086$ & $241 \pm 44.736$ & $258 \pm 75.972$ \\
\hline
\end{tabular}

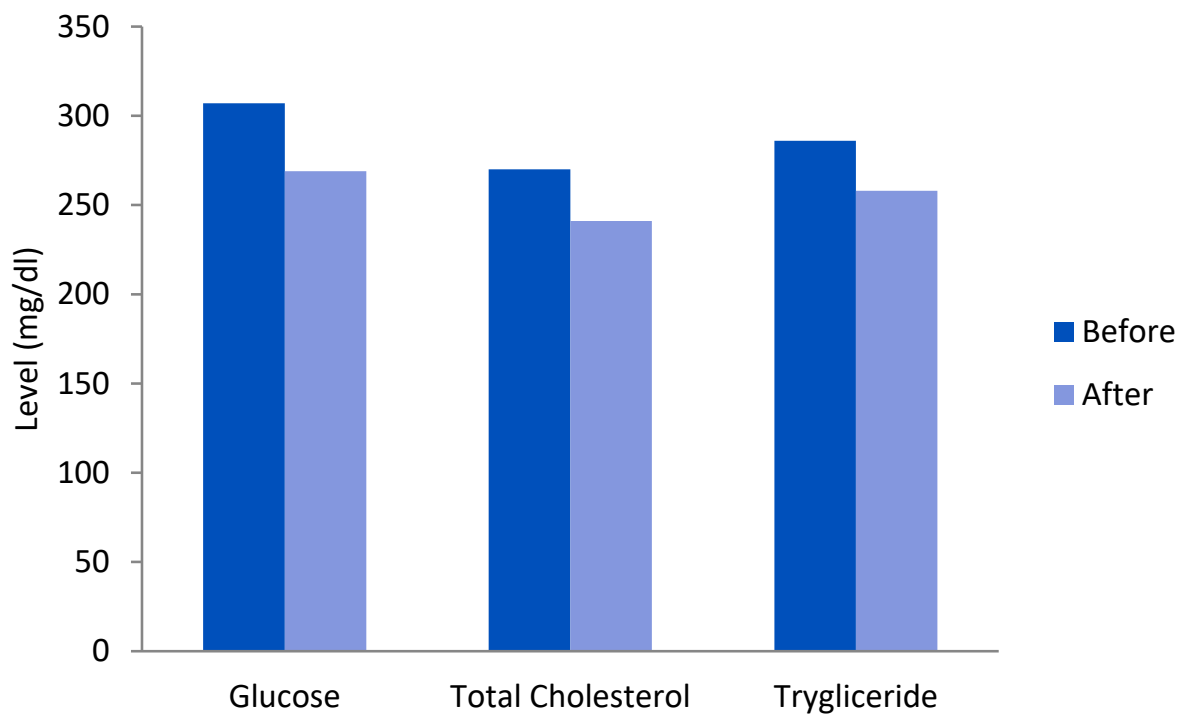

Figure 1.Average Comparison of Glucose, Cholesterol, and Triglyceride Levels Before and After HBOT

Diabetes mellitus is closely related to the lipid profile, especially concerning the cardiovascular disease. This study's data indicate that patients with diabetes 
mellitus have hyperglycemia accompanied by high levels of lipid profiles in their blood. This is in accordance with Priyadi\&Saraswati's (2012) research, showing an association between hyperglycemia and lipid profiles. This is because high blood glucose levels affect the condition of blood vessels. Under normal circumstances, insulin can increase the uptake of free fatty acids into fat tissue cells and inhibit lipolysis occurrence. However, in patients with diabetes mellitus, the amount of free fatty acids in the blood increases so that the level of lipid profile also increases and can aggravate comorbidities and complications (Sherwood, 2018).

At the time of hyperbaric oxygen therapy, hemoglobin in venous blood saturation increases the pressure of $\mathrm{O}_{2}$ in blood vessels. Oxygen diffusion is influenced by differences in pressure so that $\mathrm{O}_{2}$ from the blood vessels will be distributed to the tissues. Blood oxygen dissolves in plasma fluid bound to hemoglobin, and only a small portion found in dissolved form. Tissues more efficiently use the form of dissolved oxygen in hyperbaric oxygen therapy through direct diffusion than oxygen is bound through the hemoglobin's oxygen system (Guritno, 2005; Collins, 2015).

In this study, a significant difference obtained in blood glucose levels before and after HBOT shown by the results of significance $(p=0,000<0.05)$. This is because HBOT can increase tissue sensitivity to insulin and cause a decrease in blood sugar levels. This is consistent with the study of Zakiyah\&Anggraini (2019), which showed a significant difference $(p=0,000)$ in blood glucose levels before and after HBOT. The use of high-dose oxygen pressure of 2.4 ATA oxygen $3 \times 30$ minutes for $2 \times 5$ days interspersed with a one-week break can cause an increase in blood insulin levels in people with diabetes mellitus, due to increased pancreatic beta-cell function resulting in increased levels of insulin in the blood (Ishihara, 2007; Jain, 2017).

The data of this study indicate a significant decrease in blood glucose levels and lipid profiles, namely, total cholesterol $(p=0,000)$ and triglycerides $(p=0,000)$. This is consistent with studies in Turkey where there was a significant effect $(p$ $<0.001$ ) on blood glucose levels and lipid profiles after HBOT and showed that glycemic control, atherosclerosis, and inflammatory markers significantly improved in patients undergoing HBOT in patients with diabetes mellitus with diabetic foot ulcers (Karadurmuset al., 2010). Another study showed that HBOT could reduce total cholesterol levels $(p<0.05)$ and triglycerides levels $(p<0.05)$ in diabetes mellitus patients. In patients with diabetes mellitus, metabolic changes can damage vasodilation and causes tissue hypoxia and microvascular pathology. HBOT can significantly improve the outcome of ischemic conditions and reduce vascular complications (Resanovic, 2019).

HBOT has no adverse effect on the function of High-Density Lipoprotein and carries the potential to cause changes in lipid metabolism that can reduce atherosclerosis in patients (Erenet al., 2019). 100\% oxygen therapy can increase five times the volume of dissolved oxygen to $15 \mathrm{ml}$ per liter of blood, and during HBOT at 2.5 ATA, almost $60 \mathrm{ml}$ of dissolved oxygen in each liter of blood (Londahl, 2012). Increased oxygen in the blood can increase cells and body tissues and metabolism in cells to increase tissue sensitivity to insulin and reduce blood glucose levels (Ishihara, 2007). HBOT has the same effect as exercise so it can activate AMPK (AMP-activated protein kinase), so glucose can be used as an energy resource (ATP), which affects vasodilation by stimulating Synthase Oxid nitrate (NOS) and increasing insulin sensitivity through AMPK activation (Isbandiati, 2011). Nitric oxide synthase (NOS) activity needed for mobilization of SPC (stem/progenitor cells) from 
the bone marrow. SPC mobilization disrupted in patients with diabetes due to reduced activity of nitric oxide synthase caused by hyperglycemia and insulin resistance. HBOT can mobilize SPC by stimulating NOS in the bone marrow (Londahl, 2012).

HBOT can provide the effect of restoring vascular reactivity through modulation of vasoconstrictor and vasodilator production and increasing vessel sensitivity to these factors (Karadurmuset al., 2010). Lipid peroxidation has a relationship with elevated blood glucose levels and high oxidative stress in patients with diabetes mellitus. Improved lipid profile in diabetes mellitus, especially with foot ulcers induces overexpression of lipid peroxidase, superoxide dismutase (SOD) activity, and catalase, which suggest compensatory mechanisms by the body to prevent further tissue damage (Bhattacharyya et al., 2019). The potential effects of HBOT on endothelial function cause a significant reduction in atherosclerotic, glycemic, and inflammatory markers. Endothelial dysfunction is closely related to the development of diabetic retinopathy, nephropathy, and atherosclerosis in diabetic patients. Also, endothelial dysfunction is closely related to insulin resistance so that increased tissue sensitivity to insulin increases vascular endothelial function and vice versa.

This study has several limitations. Patients used as research subjects have a small amount with various comorbidities and drugs used for their disease management. The study also did not consider the number of times hyperbaric oxygen therapy had been undertaken by diabetes mellitus patients. In future studies, a higher number of patients and more complete examination parameters needed to find theeffect of hyperbaric oxygen therapy on patients with diabetes mellitus.

\section{CONCLUSION}

There is a significant decrease in blood glucose level and lipid profile (total cholesterol, and triglycerides) after hyperbaric oxygen therapy (HBOT).

\section{ACKNOWLEDGEMENT}

Direktorat Riset dan Pengabdian Masyarakat (DRPM) Universitas Muhammadiyah Sidoarjo and Tiandte Gedangan Sidoarjo Clinic which has facilitated the implementation of this research.

\section{CONFLICT OF INTEREST}

The authors have no potential conflicts of interest with regard to this study.

\section{REFERENCE}

Bhattacharyya, P. K., Biswas, P., Jana, D., Mukherjee, J., \& De, M. (2019). Study of lipid profile, lipid peroxidase, glutathione peroxidase, superoxide dismutase, and catalase in diabetes and non-diabetic foot ulcer patients. Journal of Dental and Medical Sciences (IOSR-JDMS), 18(2), 49-54.

Collins, J.A., Rudenski, A., Gibson, J., Howard, L., \&O'Driscoll, R. (2015). Relating oxygen partial pressure, saturation, and content: the hemoglobinoxygendissociation curve. Breathe, vol 11, 194-201.

Eren, E., Yilmaz, N., Yildirim, F., \&Giray, O. (2019).HDL functionality in patients with hyperbaric oxygen therapy. Internet Journal of Medical Update, 14(1), 5-10.

Guritno, M. (2005). Hyperbaric oxygen therapy in the treatment of the diabetic foot. The Indonesian orthopedic. Association. $50^{\text {th }}$ continuing orthopedic association. Mataram. 4-5. 
Ishihara, A. (2007). Hyperbaric exposure in rate mascle and nerve laboratory ofmetabolism graduate school of human genomic drug discovery science. Japan: Kyoto University.

Jain, K.K. (2017). Textbook of Hyperbaric Medicine. Switzerland: Springer.

Karadurmus, N., Sahin, M., Tasci, C., Naharci, I., Ozturk, C., Ilbasmis, S., Dulkadir, Z., Sen, A., \&Saglam, K. (2010). Potential benefits of hyperbaric oxygen therapy on atherosclerosis and glycaemic control in patients with a diabetic foot. Endokrynol Pol, 61(3), 275-279.

Kemenkes RI. (2018). Riset Kesehatan Dasar. Jakarta: Badan Penelitian dan Pengembangan Kesehatan Kementrian Kesehatan RI.

Lakesla.(2009). Ilmu Kesehatan Penyelaman dan Hiperbarik. Surabaya: Lembaga Kesehatan Kelautan TNI AL.

Ndisang, J.F., Vannacci, A., \&Rastogi, A. (2017). Insulin resistance, type 1 dan type 2 diabetes, and related complications. Journal of Diabetes Research. Article ID 1478294.

Poretsky, Leonit. (2010). Principles of diabetes mellitus. London: Spriner.

Putri, I. A. A., \&Setianingsih, H. (2019). Pengaruh Pemberian Oksigen Hiperbarik terhadap Kadar LDL Tikus Putih (Rattus norvegicus) Sparague dawley yang kemudianDiberi Diet Tinggi lemak. Jurnal IImiah Kedokteran Wijaya Kusuma, 8(1), 1-13.

Priyadi, R., \&Saraswati, M. R. (2014). Hubungan Antara Kendali Glikemik Dengan Profil Lipid Pada Penderita Diabetes MelitusTipe 2. Jurnal Medika Udayana, 3(12), 1-12.

Resanovic, I., Gluvic, Z., Zaric, B., Milovanovic, E. S., Vucic, V., Arsic, A., Nedic, O., Sunderic, M., Gligorijevic, N., Milacic, D., \& Isenovic, E. R. (2019). Effect of hyperbaric oxygen therapy on the fatty acid composition and IGFBP-1 in insulin-dependent diabetes mellitus adult patients: a pilot study. Canadian Journal of Diabetes, 44(1), 1-8.

Semadi, I. N., \&lrawan, H. (2017). Blood glucose and lipid profile in patients with a diabetic foot ulcer that underwent hyperbaric oxygen therapy. Bali Medical Journal (Bali Med J), 6(2), 405-408.

Shahriari, A., Khooshideh, M., \&Heidari, M. (2014). Disease Treated with Hyperbaric Oxygen Therapy; a literature review. Medical Hypothesis, Discovery \& Innovation Interdisciplinary Journal. 1(2), 1-9.

Sherwood, L. (2018). Fisiogi Manusia dari sel ke sistem. Edisi 8. Jakarta: EGC.

Sourabh, B., \&Guruswamy, V. (2012).Hyperbaric Oxygen and Wound Healing. Indian Journal Plastic Surgery. 45(2), 316-324.

Tangvarasittichai, S. (2017). Atherogenic Dyslipidemia: An Important Risk Factor for Cardiovascular Disease in Metabolic Syndrome and Type 2 Diabetes Mellitus Patients. Diabetes and Obesity International Journal, 2(1), 1-19.

Wahyuni, S., \&Alkaff, R. N. (2013). Diabetes Mellitus pada Perempuan Usia Reproduksi di Indonesia Tahun 2007. Jurnal Kesehatan Reproduksi, 3(1), 4651.

Zaetun, S., Kerti, L. B., Srigede, L. (2015). Pengaruh Terapi Oksigen Hiperbarik Terhadap Kadar Gula Darah Pasien Diabetes Mellitus di Instalasi Kesehatan Penyelaman dan Hiperbarik Kantor Kesehatan Pelabuhan Kelas II Mataram. Media Binallmiah, 9(2), 13-18.

Zakiyah, A., \&Anggraini, V. S. (2019). Hyperbaric Oxygen Therapy To Reduce Blood Glucose Level On Patients Diabetes Mellitus. Journal of Nursing Care, 2(1), 57-64. 